\title{
Optimalisasi Kinerja Karyawan terhadap Kelancaran Operasional Keagenan Kapal di Perusahaan Pelayaran
}

\author{
Titis Ari Wibowo ${ }^{1}$, Agus Leonard Togatorop ${ }^{2}$, Laurensia M. Lumban Tobing ${ }^{3}$ \\ ${ }^{1,2,3}$ Prodi Ketatalaksanaan Angkutan Laut dan Kepelabuhanan \\ Sekolah Tinggi Ilmu Pelayaran, Jakarta \\ Jl. Marunda Makmur No. 1 Cilincing, Jakarta Utara. Jakarta 14150
}

\begin{abstract}
Abstrak
Bahari Eka Nusantara Company in Jakarta is one of the major shipping companies operating in most countries in Asia engaged in agency. Bahari Eka Nusantara Company also an agent company and active on job for agents in between an international vessel and national vessel which have duties and function as an executor for clearance in and clearance out vessel operational, also service charterer who need an agent for take care of there crew document in Jakarta area. The purpose of this research is to know how big the optimization of employees towards the smooth operation of the agency. The research done by processing data of the employee for 2017-2018. For maritime company must pay an attention to a case that an create a standard of competency expected, increase the motivation of employee on their responsibility that was given by the company, to create a performance that have an important role for company value.
\end{abstract}

Copyright $($ C 2020, Prosiding Seminar Pelayaran dan Riset Terapan

Kata Kunci: Kompetensi, Kinerja, Sumber Daya Manusia kualitas, air ketel, analisis

Permalink/DOI : https://doi.org/10.36101/pcsa.v2i1.128

\section{PENDAHULAN}

Indonesia merupakan negara kepulauan dimana sebagian besar dari seluruh luas Indonesia adalah perairan. Indonesia adalah negara yang indah, kaya akan beraneka ragam suku, bahasa dan budaya. Keanekaragaman ini terbentang dari Sabang hingga Merauke. Beraneka macam objek wisata pun menawarkan keindahan dan ciri khas tersendiri disetiap tempat di Indonesia. Pariwisata Indonesia satu sektor yang sangat diandalkan dalam pembangunan nasional karena pariwisata dapat maningkatkan pendapatan nasional dan pendapatan daerah serta devisa negara.

Banyak manfaat yang dapat diperoleh dari sektor pariwisata di Indonesia. Salah satu pemanfaatan yang dilakukan Indonesia dalam menjaga kestabilan ekonomi negara yaitu melalui sektor pelayaran, yaitu dengan melakukan kerjasama melalui perdagangan antar negara melalui jalur pelayaran bongkar dan muat barang, serta melakukan perjalanan bagi turis asing menggunakan kapal pesiar (cruise). Di Indonesia telah banyak sektor pelayaran yang tersebar di setiap daerah. Diantaranya perusahaan pelayaran yang bergerak di bidang keagenan kapal. Angkutan laut asing yang kapalnya melakukan kegiatan angkutan laut ke dan dari pelabuhan Indonesia yang terbuka untuk perjalanan dan perdagangan luar negeri wajib menunjuk perusahaan angkutan nasional yang memenuhi persyaratan yang ditentukan sebagai agen umum. Keagenanan adalah perusahaan pelayaran yang ditunjuk oleh perusahaan pelayaran asing di luar negeri (selaku principal) untuk mengurus segala sesuatu yang berkaitan dengan kepentingan kapal tersebut.

Disinilah seorang pemilik kapal berlaku sebagai principal menunjuk agen yang bersedia guna memberikan fasilitas pelayanan yang dibutuhkan dari perusahaan pelayaran dan kapal asing yang akan memasuki perairan Indonesia sesuai dengan ketetapan UU No. 17 tahun 2008. Tenaga kerja di perusahaan merupakan salah satu faktor penting yang harus diperhatikan oleh perusahaan dalam rangka mencapai tujuannya. Disini dituntut kemampuan perusahaan untuk mengelola sumber-sumber daya secara terencana, terutama kemampuan sumber daya sebagai tenaga pelaksana operasional perusahaan untuk menghasilkan daya guna dan hasil dalam setiap kegiatan perusahaan.

Dengan demikian perusahaan tidak hanya dapat mempertahankan keuntungan yang diperoleh, tetapi juga dapat mempertahankan eksistensisnya dalam dunia usaha. Untuk mendapatkan hasil yang baik maka para tenaga kerja tersebut harus diberi bekal pengetahuan 
dan keterampilan yang cukup, karena tenaga kerja penting dalam mencapai tujuan perusahaan.

Berbagai usaha telah dilakukan oleh pemimpin perusahaan. Mereka telah menyadari berhasil atau tidaknya tujuan perusahaan tergantung pada unsur manusianya. Oleh karena itu dalam usaha untuk memperoleh dan meningkatkan prestasi kerja yang baik tidak hanya melalui cara penarikan tenaga kerja yang tepat tetapi juga harus didukung usaha yang diantaranya melalui pelatihan tenaga kerja.

Meskipun pelatihan tenaga kerja memerlukan biaya yang tidak sedikit, tetapi pelatihan harus tetap dilaksanakan karena pelatihan tersebut mempunyai manfaat yang sangat besar, baik bagi perusahaan maupun bagi karyawan perusahaan. Perkembangan perusahaan dipengaruhi oleh perkembangan teknologi. Untuk dapat berkembang, selain di dukung oleh sistem manajeman yang juga disertai dengan penggunaan mesin-mesin dan peralatan-peralatan yang lebih canggih, baik untuk keperluan operasional maupun administrasi perusahaan.

Disini mau tidak mau perusahaan harus mampu menyediakan dan menciptakan tenaga kerja yang terampil, cakap, ahli serta siap pakai dalam melaksanakan pekerjaan-pekerjaan yang semakin manuntut kemampuan kerja yang lebih tinggi.

Peranan ini biasanya diwujudkan dalam bentuk sumbangan kemampuan dan potensi terhadap pelaksanaan tugas-tugas yang berhubungan dengan kegiatan perusahaan yang bersangkutan. Agar peranan itu selalu membuahkan hasil yang optimal, dibutuhkan suatu program pelatihan yang terus menerus bagi para pegawai baik yang baru saja diterima maupun yang sudah lama bekerja di dalam perusahaan. Tidak jarang pula karyawan yang baru diterima tidak mempunyai kemampuan secara penuh untuk melaksanakan tugas dan pekerjaan mereka. Bahkan karyawan yang sudah berpengalaman pun perlu belajar dan menyesuaikan dengan kabijakan dan prosedur yang telah ditetapkan oleh perusahaan. Mereka juga mungkin memerlukan latihan dan pengembangan lebih lanjut untuk mengerjakan pekerjaan mereka secara profesional.
Demikian halnya PT Bahari Eka Nusantara yang bergerak dibidang keagenan kapal yang menginginkan agar karyawan dapat bekerja dengan baik, sehingga dapat memberikan dan menghasikan keuntungan bagi perusahaan. Akan tetapi, karyawan PT Bahari Eka Nusantara yang masih memiliki pengetahuan yang rendah mengenai tugas keagenan kapal karena penerimaan karyawan yang tidak sesuai dengan kemampuan dan keterampilan dibidang keagenan kapal, sehingga kewajiban yang diberikan dan dibebankan kepada mereka terpenuhi secara optimal.

Berdasarkan latar belakang permasalahan yang dikemukakan diatas, maka peneliti mengidentifikasikan masalah sebagai berikut :

1. Rendahnya kinerja karyawan divisi operasional

2. Rendahnya keterampilan karyawan divisi operasional dalam melakukan kegiatan keagenan kapal.

3. Tingginya angka pengunduran diri dalam masa percobaan.

4. Tingkat pendidikan yang masih rendah.

Dari identifikasi masalah diatas dapat dibatasi sebagai berikut:

1. Rendahnya kinerja karyawan divisi operasional.

2. Rendahnya keterampilan karyawan divisi operasional dalam melakukan kegiatan keagenan kapal.

Dalam penulisan penelitian ini, peneliti mengangkat tentang permasalahan yang berkaitan dengan pelatihan karyawan, maka permasalahan yang harus dipecahkan adalah sebagai berikut:

1. Apa penyebab rendahnya kinerja divisi operasional?

2. Apa penyebab rendahnya keterampilan karyawan divisi operasional dalam melakukan kegiatan keagenan kapal?

Lebih lanjut, tujuan penelitian ini antara lain :

1. Untuk mengetahui dan menganalisa penyebab rendahnya kinerja karyawan divisi operasional.

2. Untuk mengetahui penyebab rendahnya keterampilan karyawan.

\section{METODE}

Dengan permasalahan yang diangkat dalam penelitian ini, peneliti menggunakan metode 
pendekatan deskriptif kualitatif. Dalam pembahasan masalah yang ada, peneliti memilih teknik analisis sebab akibat yang sesuai dengan memudahkan peneliti untuk menganalisisnya berdasarkan data yang telah ada. Analisis sebab akibat ini menganalisis sesuatu kejadian dan peristiwa yang terjadi dengan meneliti akar dan penyebab dari permasalahan yaitu mengenai kurangnya kinerja divisi operasional PT Bahari Eka Nusantara yang menyebabkan seringnya terjadi kesalahan dalam laporan aktivitas kapal asing di Indonesia. Untuk lebih mempermudah dalam memahami permasalahan ini, maka peneliti menggunakan SWOT deskriptif menganalisis SWOT (Strength, Weakness, Opportunity, dan Threat).

\section{HASIL DAN PEMBAHASAN}

PT Bahari Eka Nusantara adalah salah satu perusahaan pelayaran yang telah berdiri sejak tahun 1994 yang hanya bergerak dibidang keagenan kapal. Perusahaan ini sudah memiliki lebih dari 30 cabang di seluruh Indonesia dan melayani segala kebutuhan kapal milik perusahaan lokal maupun asing. Pelayanan yang ditawarkan oleh perusahaan ini adalah pelayanan dokumen clearance in dan clearance out, pengurusan dokumen bongkar dan muat, pengurusan awak kapal dan juga pengurusan segala kepeerluan kapal itu sendiri, seperti pengisian bahan bakar (Bunker) dan pengisian air tawar (Fresh Water).

Dalam memudahkan penelitan, peneliti akan menyampaikan deskripsi mengenai data yang berkaitan dengan masalah yang ditulis. Pada saat itu peneliti melaksanakan pengamatan terjadinya penurunan kunjungan kapal yang disebabkan oleh kurangnya kinerja agen yang belum optimal. Peneliti menemukan banyak hal yang seharusnya diperbaiki dalam manajemen perusahaan, misalnya kurangnya jumlah karyawan dalam mengageni kapal yang seharusnya tidak ditangani dalam jumlah sedikit membuat keagenan tersebut menjadi kurang optimal dalam melayani kunjungan kapal.

Ditambah lagi, kinerja dari karyawan itu sendiri yang kurang sigap dalam menghadapi masalah tersebut seperti kemampuan dalam berbahasa asing yang sangat minim membuat agen sulit dalam berkomunikasi dengan kapalkapal yang berbendera asing dan kurangnya kemampuan dalam pengoperasian komputer.

Berikut ini disajikan tabel tentifikasi Faktor

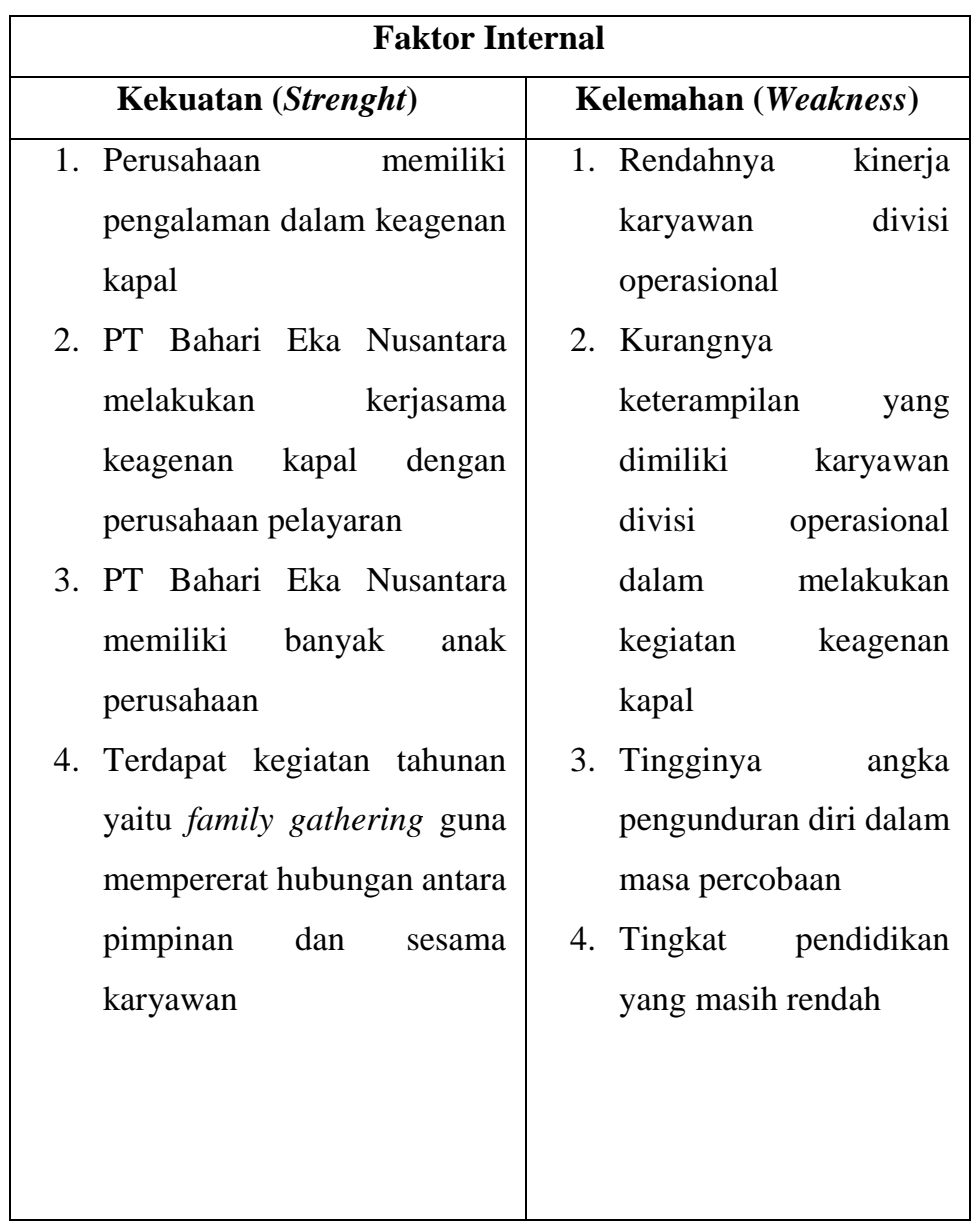

Internal dan Eksternal perusahaan.

\begin{tabular}{|c|c|}
\hline \multicolumn{2}{|c|}{ Faktor Eksternal } \\
\hline Peluang (Opportunities) & Ancaman (Threats) \\
\hline $\begin{array}{l}\text { 1. Kunjungan kapal di } \\
\text { Indonesia yang cukup } \\
\text { tinggi } \\
\text { 2. Banyaknya jumlah kapal } \\
\text { yang dapat diageni. } \\
\text { 3. Adanya kepercayaan yang } \\
\text { diberikan pelanggan } \\
\text { terhadap perusahaan. }\end{array}$ & $\begin{array}{l}\text { 1. Hilangnya kepercayaan } \\
\text { para principal terhadap } \\
\text { perusahaan bila kapal } \\
\text { tidak diageni dengan } \\
\text { baik } \\
\text { 2. Banyaknya perusahaan } \\
\text { keagenan kapal. } \\
\text { 3. Banyaknya perusahaan } \\
\text { baru yang bergerak } \\
\text { dalam bidang keagenan } \\
\text { kapal }\end{array}$ \\
\hline
\end{tabular}


Identifikasi faktor internal dan eksternal dilakukan dengan teknik Brainstorming yang diperkenalkan oleh Alex Osborn, yaitu mengidentifikasi sejumlah kemampuan sumber daya internal yang dapat diandalkan, diklasifikasi atau dikelompokkan ke dalan kategori kekuatan (Strenght), dan kelemahan (Weakness), sedangkan faktor eksternal dikelompokkan didalam kategori Peluang (Oppurtunities) dan Ancaman (Threats).

Hasil identifikasi faktor internal dan eksternal sebagai berikut:

a. Kekuatan (Strenght)

1) PT Bahari Eka Nusantara memiliki pengalaman dalam keagenan kapal

PT Bahari Eka Nusantara merupakan perusahaan pelayaran yang bergerak dibidang keagenan kapal yang berdiri sejak tahun 1994 dan sudah banyak menangani kapal-kapal yang memasuki wilayah Indonesia, dalam hal ini sudah tentu sudah berpengalaman dalam menangani kapal baik yang berbendera asing maupun kapal lokal.

2) PT Bahari Eka Nusantara melakukan kerjasama keagenan kapal dengan perusahaan pelayaran

Perusahaan melakukan kerjasama keagenan kapal dengan perusahaan pelayaran terbukti dengan adanya shipowner/principal tetap yang sudah bekerja sama dengan PT Bahari Eka Nusantara seperti Libra Shipping Service Ocean Transport, Cory Brother Shipping Agency LTD, SAL Heavy Lift GMBH, Lafarge Cement Indonesia, Royal Caribbean Cruise Line dan Maestro Shipping sehingga tidak perlu takut kehilangan pengguna jasa dalam persaingan.

3) PT Bahari Eka Nusantara memiliki banyak anak perusahaan

PT Bahari Eka Nusantara sudah memiliki 30 anak perusahaan yang tersebar di wilayah Indonesia. Hal ini tentu menjadi salah satu keunggulan dalam menambah jumlah pelanggan yang akan menggunakan jasa keagenan perusahaan ini.

4) Terdapat kegiatan tahunan yaitu family gathering guna mempererat hubungan antara pimpinan dan sesama karyawan.
Family gathering itu sendiri adalah kegiatan yang ditujukan bagi suatu perusahaan yang berupa kegiatan kumpul bersama yang dikemas dalam acara rekreasi yang bertujuan untuk membangun keakraban atau kebersamaan. Dilakukan family gathering yaitu sebagai sarana refreshing agar karyawan tidak stres, membentuk kerja tim yang solid dan juga upaya untuk menciptakan rasa kekeluargaan antara pimpinan dan antar sesama karyawan. Dapat dirasakan pada perusahaan PT Bahari Eka Nusantara telah memiliki rasa kekeluargaan antara pimpinan dan antara sesama karyawan yang tercipta karena adanya kegiatan family gathering tersebut sehingga karyawan dalam melakukan pekerjaannya tidak merasa tertekan melainkan merasa nyaman sehingga pekerjaan yang sedang dikerjakan dapat terselesaikan dengan baik dan tepat waktu.

b. Kelemahan (Weakness)

1) Rendahnya kinerja karyawan divisi operasional

Jika kinerja karyawan rendah maka tidak akan sesuai dengan target perusahaan yang berdampak pada penurunan keagenan kapal.

2) Rendahnya keterampilan yang dimiliki oleh karyawan divisi operasional dalam melakukan kegiatan keagenan kapal Selain jumlah sumber daya manusia, faktor keterampilan juga menjadi salah satu nilai tambah bagi perusahaan. Perusahaan PT Bahari Eka Nusantara merupakan perusahaan keagenan yang menangani kapal asing, secara tidak langsung hal itu membuat karyawan perusahaan harus memiliki keterampilan berbahasa inggris. Selain itu karyawan juga harus memilki keterampilan mengenai keagenan kapal agar membuat pelayanan kapal pada perusahaan dapat meningkat. Namun menurut penelitian peneliti, karyawan pada perusahaan masih belum memiliki keterampilan yang baik dalam segi bahasa inggris maupun keterampilan tentang keagenan. Kurangnya keterampilan karyawan PT 
Bahari Eka Nusantara membuat perusahaan perlu mengadakan pelatihan kepada karyawan perusahaan agar kepercayaan para pelanggan dapat bertambah sehingga dapat menambah jumlah pelanggan yang akan diageni oleh perusahaan.

3) Tingginya angka pengunduran diri dalam masa percobaan

Tingginya angka pengunduran diri dalam masa percobaan ini terjadi karena banyaknya tuntutan pekerjaan namun tidak sesuai dengan upah yang diterima. Oleh karena itu banyak calon karyawan yang mengundurkan diri karena ketidaksesuaian pekerjaan yang dikerjakan dengan upah yang mereka terima.

4) Tingkat pendidikan yang masih rendah Tingkat pendidikan karyawan juga salah satu faktor yang harus ditingkatkan karena pengetahuan akan keagenan masih kurang. Hal ini menjadi salah satu pengaruh kurangnya kinerja perusahaan.

c. Peluang (Oppurtunity)

1) Kunjungan kapal di Indonesia yang cukup tinggi

Dengan banyaknya jumlah kapal yang memasuki wilayah Indonesia baik kapal berbendera asing maupun berbendera Indonesia, tentunya akan menjadi peningkatan dalam pelayanan keagenan kapal.

b) Banyaknya jumlah kapal yang dapat diageni

Dengan banyaknya kapal yang masuk di Indonesia, peluang untuk mengageni kapal semakin besar, hal ini dapat meningkatkan pendapatan perusahaan.

c) Adanya kepercayaan yang diberikan pelanggan terhadap perusahaan.

Kepercayaan dalam hal berbisnis sangat diperlukan, karena kepercayaan menjadi salah satu faktor pendukung keberhasilan suatu perusahaan. Dengan adanya kepercayaan yang diberikan pelanggan terhadap perusahaan akan menjadikan pelanggan atau pengguna jasa tersebut akan tetap memakai jasa keagenan perusahaan yang dimana pelanggan tidak akan berpindah ke perusahaan lain. Dengan adanya kepercayaan yang telah diberikan terhadap perusahaan juga dapat meningkatkan kualitas perusahaan dan akan menambah jumlah kapal yang akan diageni oleh perusahaan.

d. Ancaman (Threat)

1) Hilangnya kepercayaan para principal terhadap perusahaan bila kapal tidak ditangani dengan baik

Dalam hal ini pihak principal sangat menilai penanganan kapal-kapal yang akan dilayani, perusahaan harus memberikan pelayanan yang baik untuk dapat mempertahankan principal untuk selalu menjadi pelanggan tetap perusahaan

2) Banyaknya perusahaan keagenan kapal Dengan adanya perusahaan lain sejenis yang bergerak dibidang keagenan kapal, akan menjadi ancaman bagi perusahaan karena persaingan menjadi ketat

3) Banyaknya perusahaan baru yang bergerak dalam bidang keagenan kapal

Seperti yang kita ketahui bahwa pelabuhan Indonesia yang sudah memadai berpotensi akan meningkatkan jumlah arus kapal yang akan masuk ke daerah perairan Indonesia dan akan membuat beberapa pihak dari masyarakat tergerak untuk membuat usaha khususnya dalam bidang keagenan kapal. Hal ini merupakan suatu ancaman bagi perusahaan, ancaman ini dapat menimbulkan kerugian bagi perusahaan. Oleh karena itu, PT Bahari Eka Nusantara perlu meningkatkan pelayanan menjadi lebih baik lagi sehingga pengguna jasa keagenan tidak berpindah kepada perusahaan keagenan yang lain.

Faktor-faktor yang telah dikelompokkan atas dasar faktor internal dan eksternal akan dilakukan identifikasi kembali untuk menentukan masing-masing faktor dalam kategori kekuatan, kelemahan, peluang, dan ancaman. Faktor internal sebagai faktor yang mempengaruhi dari dalam dan Faktor eksternal sebagai faktor yang mempengaruhi dari luar akan dimasukkan dalam kategori kekuatan dan kelemahan. 
http://ejournal.stipjakarta.ac.id/index.php/pcsa

Strategi merupakan sarana untuk mencapai tujuan. Strategi yang ditetapkan adalah yang memadukan antara kekuatan dan peluang (Strenght dan Oppurtunity), kelemahan dan peluang (Weakness dan Oppurtunity), kekuatan dan ancaman (Strenght dan Threats), kelemahan dan ancaman (Weakness dan Threats). 


\begin{tabular}{|c|c|c|}
\hline \multirow[b]{2}{*}{ INTERNAL } & \multicolumn{2}{|c|}{ httKelkjatanal(Stipjakarta.ac.id/index.php/pcsa Kelemahan (W) } \\
\hline & $\begin{array}{l}\text { 1. PT Bahari Eka Nusantara } \\
\text { memiliki pengalaman dalam } \\
\text { keagenan kapal } \\
\text { 2.PT Bahari Eka Nusantara } \\
\text { melakukan rerjasama } \\
\text { keagenan kapal dengan } \\
\text { perusahaan pelayaran }\end{array}$ & $\begin{array}{l}\text { 1. Rendahnya kinerja karyawan divisi operasional } \\
\text { 2. Rendahnya keterampilan yang dimiliki oleh } \\
\text { karyawan divisi operasional dalam melakukan } \\
\text { kegiatan keagenan kapal }\end{array}$ \\
\hline Peluang (O) & & WO \\
\hline $\begin{array}{l}\text { 1. Kunjungan kapal di } \\
\text { Indonesia yang cukup } \\
\text { tinggi } \\
\text { 2. Banyaknya jumlah } \\
\text { kapal yang dapat } \\
\text { diageni }\end{array}$ & $\begin{array}{l}\text { 1.1 Dengan pengalaman yang } \\
\text { dimiliki perusahaan dalam } \\
\text { mengageni kapal dapat } \\
\text { menambah nilai jual } \\
\text { perusahaan di mata principal } \\
\text { sehingga dapat menangani } \\
\text { kunjungan kapal di } \\
\text { Indonesia yang cukup tinggi } \\
\text { 2.2 Dengan melakukan } \\
\text { kerjasama keagenan kapal } \\
\text { dengan perusahaan } \\
\text { pelayaran banyak kapal yang } \\
\text { dapat diageni oleh } \\
\text { perusahaan }\end{array}$ & $\begin{array}{l}\text { 1.1 Merekrut karyawan yang profesional sesuai } \\
\text { standar perusahaan yang dibutuhan oleh masing- } \\
\text { masing divisi } \\
\text { 1.2 Memberikan pelatihan dan pendidikan kepada } \\
\text { karyawan seputar keagenan pelayaran dan kursus } \\
\text { bahasa inggris sehingga karyawan dapat } \\
\text { menangani banyak kapal dengan maksimal }\end{array}$ \\
\hline Ancaman (T) & 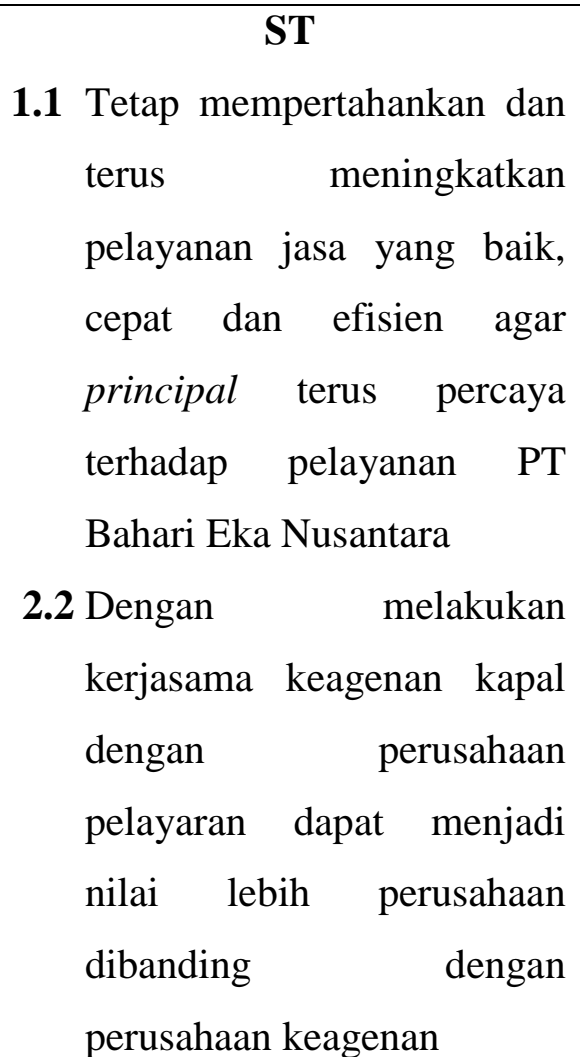 & $\begin{array}{l}\text { WT } \\
\text { 1.1 Peningkatan kinerja karyawan dalam jasa } \\
\text { pelayanan kapal dapat membuat principal tetap } \\
\text { bekerjasama dengan PT Bahari Eka Nusantara } \\
\text { a. Penerapan pendidikan dan pelatihan guna } \\
\text { meningkatkan kegiatan operasional dalam } \\
\text { menghadapi tingkat persaingan dengan } \\
\text { perusahaan keagenan lain }\end{array}$ \\
\hline
\end{tabular}


Dari pembahasan tentang penggunaan tekni analisis Strength, Weakness, Opportunities, dan Threat (SWOT) sebagai teknik analisis, adapun strategi dari analisis sebagai berikut:

a. Strategi SO

1) Dengan pengalaman yang dimiliki perusahaan dalam mengageni kapal dapat menambah nilai jual perusahaan di mata principal sehingga dapat menangani kunjungan kapal di Indonesia yang cukup tinggi.

2) Dengan melakukan kerjasama keagenan kapal dengan perusahaan pelayaran banyak kapal yang dapat diageni oleh perusahaan

b. Strategi ST

1) Tetap mempertahankan dan terus meningkatkan pelayanan jasa yang baik, cepat dan efisien agar principal terus percaya terhadap pelayanan PT Bahari Eka Nusantara

2) Dengan melakukan kerjasama keagenan kapal dengan perusahaan pelayaran dapat menjadi nilai lebih perusahaan dibanding dengan perusahaan keagenan

c. Strategi WO

1) Merekrut karyawan yang profesional sesuai standar perusahaan yang dibutuhan oleh masing-masing divisi

2) Memberikan pelatihan dan pendidikan kepada karyawan seputar keagenan pelayaran dan kursus bahasa inggris sehingga karyawan dapat menangani banyak kapal dengan maksimal

d. Strategi WT

1) Peningkatan kinerja karyawan dalam jasa pelayanan kapal dapat membuat principal tetap bekerjasama dengan PT Bahari Eka Nusantara

2) Penerapan pendidikan dan pelatihan guna meningkatkan kegiatan operasional dalam menghadapi tingkat persaingan dengan perusahaan keagenan lain

Dari hasil analisis diatas dapat juga diuraikan sebagai berikut banyaknya kapalkapal yang melakukan kegiatan di pelabuhan Indonesia sangatlah membutuhkan perusahaan keagenan untuk mengurusi segala kegiatan kapal. Sudah seharusnya PT Bahari Eka
Nusantara mampu mengageni kapal dalam jumlah yang banyak dengan memberikan pelayanan yang terbaik kepada pengguna jasa keagenan kapal, namun ternyata faktor dari dalam perusahaan dan luar perusahaan yang membuat PT Bahari Eka Nusantara menjadi kurang diminati oleh pengguna jasa keagenan disebabkan oleh pelayanan yang diberikan masih belum optimal sehingga membuat pengurusan pelayanan kapal menjadi terhambat dan banyaknya perusahaan keagenan lain yang dimiliki pelayanan yang lebih baik. Oleh karena itu perlu ditemukan solusi untuk meningkatkan pelayanan kapal dan mengurangi resiko yang disebabkan oleh persaingan dengan perusahaan keagenan lainnya.

Adapun cara yang ditempuh adalah sebagai berikut :

1) Menambah jumlah karyawan yang profesional, pihak perusahaan hendaknya menambah jumlah karyawan terutama penambahan karyawan pada divisi operasional. Kegiatan ini diharapkan sesuai dengan standar perusahaan agar kinerja karyawan meningkat dan mempermudah kegiatan operasional perusahaan.

2) Pemberian bonus serta reward, pemberian bonus dan reward kepada karyawan yang berprestasi dan karyawan yang mempunyai jenjang karir yang cukup lama agar lebih giat dan antusias dalam bekerja.

3) Pemberian pelatihan dan pendidikan keagenan, peningkatan kualitas karyawan dalam kegiatan operasional yaitu dengan pemberian pendidikan dan pelatihan sehingga memiliki kemampuan dalam melaksanakan kegiatan pelayanan keagenan secara maksimal.

4) Meningkatkan sikap disiplin dalam bekerja, dalam sikap pekerjaan diperlukan sikap dan perilaku taat mematuhi peraturan yang ada agar siklus kegiatan berjalan lancar tanpa ada hambatan.

Dalam rangka menganalisis permasalahan yang telah dikemukakan di atas, peneliti mencoba untuk memberikan suatu pemecahan yang terbaik dari beberapa alternatif yang 
diberikan. Alternatif pemecahan masalah adalah suatu solusi yang dapat digunakan untuk memecahkan masalah setelah peneliti menganalisis dari data yang ada. Berdasarkan penjelasan-penjelasan yang telah peneliti ungkapkan, mulai dari permasalahan yang diberikan hingga pemecahannya yang dilandasi atas teori-teori yang digunakan dengan mengurutkannya dari alternatif yang paling baik yang dapat dilakukan oleh instansi maka alternatif - alternatif yang dapat digunakan PT Bahari Eka Nusantara dalam rangka meningkatkan produktifitas bongkar muatnya dapat melakukan beberapa cara, antara lain :

\section{Rendahnya kinerja karyawan divisi operasional}

a. Menambah karyawan yang profesional Pihak perusahaan hendaknya menambah karyawan yang profesional yang sesuai standar perusahaan, terutama karyawan pada divisi operasional. Hal ini bertujuan untuk meningkatkan kinerja karyawan dan mempermudah kegiatan operasional perusahaan. Dalam penambahan karyawan perlu juga diperhatikan latar belakang pendidikan berbasis pelayaran, agar proses pengurusan dan pelayanan kapal dapat berjalan dengan lancar. Namun perlu diperhatikan segi pengeluaran tunjangan atau gaji untuk karyawan.

b. Pemberian bonus serta reward

Pemberian bonus dan reward kepada karyawan yang berprestasi dan karyawan yang mepunyai jenjang karir yang cukup lama agar lebih giat dan antusias dalam bekerja. Hal ini dapat dilakukan dengan:

1) Pemberian tunjangan-tunjangan seperti: tunjangan kesehatan, tunjangan hari raya, tunjangan transportasi, dan tunjangan makan karyawan.

2) Pemberian hadiah dan penghargaan kepada karyawan yang berprestasi dalam pekerjaan yang dapat menyelesaikan dengan cepat dan tepat. Serta kepada karyawan yang telah loyal lama bekerja dengan perusahaan, seperti memberikan kenaikan jabatan.

2. Kurangnya keterampilan yang dimiliki karyawan divisi operasional dalam melakukan kegiatan keagenan kapal

a. Pemberian pelatihan dan pendidikan kepada karyawan mengenai keagenan Peningkatan keterampilan karyawan dalam kegiatan keagenan kapal yaitu dengan pemberian pelatihan dan pendidikan sehingga memiliki kemampuan dalam melaksanakan kegiatan pelayanan keagenan secara maksimal. Pelatihan dan pendidikan terhadap karyawan bermanfaat untuk meningkatkan keterampilan teknis, teoritis dan moral karyawan. Dengan demikian karyawan akan bertambah pengetahuannya dan akan meningkatkan kinerjanya.

Hal ini dapat dilakukan dengan:

1) Memberi khursus Bahasa Inggris kepada karyawan karena perusahaan juga mengageni kapal asing.

2) Memberi pendidikan tentang keagenan pada karyawan yang berlatar belakang pendidikan bukan pelayaran.

b. Meningkatkan sikap disiplin dalam bekerja

Dalam sikap pekerjaan diperlukan sikap dan perilaku taat mematuhi peraturan yang ada agar siklus kegiatan berjalan lancar tanpa ada hambatan. Semakin baik disiplin karyawan, semakin tinggi prestasi kerja yang dapat dicapainya. Tanpa disiplin yang baik, sulit bagi organisasi perusahaan mencapai hasil yang optimal. Oleh karena itu pihak manajemen harus mengadakan pelatihan yang bertujuan untuk meningkatkan kedisiplinan dan keahlian serta sikap dan mental karyawan. Untuk mengatasi karyawan perusahaan yang tidak disiplin juga dapat dilakukan dengan cara memberikan pengawasan langsung terhadap perilaku, moral, sikap, gairah, kerja, dan prestasi kerja. Selain itu, juga memberikan tindakan pembinaan dan penegakan disiplin sesuai dengan jenis 
pelanggaran yang ditetapkan oleh perusahaan.

Dari berbagai macam alternatif pemecahan masalah yang telah dikemukakan diatas, peneliti dapat mengevaluasi alternatifalternatif tersebut dengan mengurutkan berdasarkan prioritas atau alternatif yang paling baik dapat dilakukan oleh perusahaan.

\section{Menambah jumlah karyawan yang profesional}

Dengan penambahan jumlah karyawan yang profesional tentunya akan mempermudah pekerjaan karyawan, karena dengan jumlah karyawan yang ada saat ini sangat sulit untuk melayani kapal-kapal yang diageni, khususnya karyawan pada divisi operasional, dalam hal ini proses penanganan menjadi tidak teratur karena kurangnya karyawan yang dimiliki tidak sebanding dengan jumlah kapal yang akan dilayani.

\section{Kelebihan :}

Penambahan jumlah karyawan khususnya dibagian operasional berguna untuk membantu kinerja karyawan dalam mengerjakan pekerjaan dan proses pelayanan akan lebih baik, penambahan ini juga akan mengurangi beban tugas dan tanggung jawab ganda pada karyawan divisi operasional.

\section{Kelemahan :}

Dengan menambah karyawan mengakibatkan pengeluaran biaya baru bagi perusahaan untuk membayar gaji dan tunjangan karyawan baru ini, dengan adanya karyawan baru berarti fasilitas operasional kantor harus ditambah untuk menunjang kegiatannya selama di perusahaan, sehingga membutuhkan pengeluaran tambahan untuk penambahan fasilitas.

\section{Pemberian bonus serta reward}

Pemberian bonus atau reward kepada karyawan dalam hal ini dapat dipercaya menambah motivasi para karyawan didalam bekerja, dan agar para karyawan tersebut nyaman untuk bekerja diperusahaan yang ditempatinya sekarang dan mempunyai jenjang karir yang cukup lama diperusahaan, agar karyawannya lebih giat dan antusias dalam bekerja.

\section{Kelebihan :}

Pemberian bonus atau reward kepada karyawan, gunanya agar dapat memberikan motivasi karyawan yang lain untuk meningkatkan kinerjanya dalam bekerja.

\section{Kelemahan :}

Pemberian ini akan berdampak kepada perusahaan, karena perusahaan harus mengeluarkan biaya lagi, dan bagi karyawan akan lebih fokus kepada pendapatan binus daripada kinerja dari karyawan itu sendiri.

3. Pemberian pelatihan dan pendidikan keagenan

Memberikan pendidikan dan pelatihan kepada karyawan atau berupa seminar kepada karyawan yang latar belakang pendidikannya bukan dari dunia keganan atau pelayaran. Serta memberikan kursus bahasa inggris khususnya kepada karyawan di bagian operasional untuk mempermudah komunikasi dengan crew kapal asing karena perusahaan juga mengageni kapal-kapal berbendera asing.

\section{Kelebihan :}

Dengan diberikan tambahan pendidikan berupa pendidikan singkat atau seminar mengenai ilmu keagenan, kemampuan karyawan akan bertambah, sehingga karyawan tersebut mampu menjalankan tugas dan tanggung jawabnya sesuai jabatan yang dijalankannya. Dalam hal pemberian kursus bahasa inggris maka kemampuan komunikasi karyawan dengan pihak-pihak bersangkutan yang menggunakan bahasa inggris sebagai bahasa komunikasi akan bertambah, sehingga mengurangi hambatan komunikasi dalam hal keterbatasan bahasa.

\section{Kelemahan :}

Mengikuti kegiatan pendidikan akan mengganggu pekerjaan dan tanggung jawab karyawan tersebut diperusahaan. Jika pendidikan tersebut dilaksanakan pada hari libur, tentu akan menggangu waktu istirahat karyawan dan dapat menimbulkan resiko kelelehan sehingga kinerjanya di perusahaan akan menurun.

4. Meningkatkan sikap disiplin dalam bekerja

Dalam upaya meningkatkan sikap disiplin bagi karyawan perusahaan maka harus dilakukan langkah-langkah sebagai berikut: 


\section{Kelebihan :}

a. Pemberian pengetahuan kedisiplinan Dengan memberikan pengetahuan tentang disiplin bagi para karyawan dan adanya program-program yang berisi kegiatan penambahan wawasan, perbaikan sikap, dan upaya-upaya menumbuhkan rasa disiplin dalam diri para karyawan, tentunya akan menambah rasa keterikatan antara perusahaan dan karyawannya, dapat meningkatkan semangat kerja di pelabuhan.

b. Memberikan sanksi yang tepat serta pengawasan

Sanksi yang tegas akan membantu pihak menajeman perusahan untuk menerapkan ketentuan dalam upaya pencapaian target perusahaan. Sanksi dapat menimbulkan efek jera bagi pelanggarnya sehingga mampu mengarahkan para pekerja untuk mengikuti apa yang telah diarahkan oleh perusahaan, sedangkan pengawasan dapat membantu pihak manajemen dalam menjaga kontinuitas pelaksanaan ketentuan-ketentuan dalam upaya mencapai tujuan. Dampak positif jika atasan memberikan sanksi yang tegas bersama dengan tindakan pengawasan terhadap karyawannya yang tidak melaksanakan pekerjaannya dengan sesuai, yaitu :

1) Membuat karyawan akan lebih sungguh-sungguh dalam melaksanakan tugasnya sesuai dengan perintah dan arahan.

2) Dapat melatih kepatuhan bawahan kepada pimpinan dan perintah yang diberikan atasan akan didengar oleh bawahannya.

\section{Kelemahan :}

Adapun dampak negatif bisa saja terjadi individualisme pada diri karyawan dimana mereka tidak mau pekerjaannya dibantu oleh tenaga kerja yang lainnya, padahal mereka harus saling bekerja sama dalam kelompok atau tim, dan dampak negatif dari sanksi itu sendiri yaitu jika atasan terlalu menerapkan sanksi-sanksi yang terlalu tegas kepada bawahannya seperti :
1) Keahlian-keahlian yang dimiliki oleh karyawan tidak akan keluar karena karyawan terlalu takut jika terjadi kesalahan.

2) Dengan memanfaatkan peraturan yang ada, atasan akan bertindak semaunya kepada bawahannya.

3) Terjadi ketidakharmonisan apabila tidak diberikan oleh atasannya.

Setelah melakukan evaluasi terhadap setiap alternatif pemecahan masalah, maka dapat ditentukan alternatif yang tepat untuk dipilih sebagai pemecah masalah dalam mengoptimalkan kinerja dan keterampilan karyawan PT Bahari Eka Nusantara, yaitu sebagai berikut:

\section{Rendahnya kinerja karyawan divisi operasional}

a. Menambah karyawan yang profesional Pihak perusahaan hendaknya menambah karyawan yang profesional yang sesuai standar perusahaan, terutama karyawan pada divisi operasional. Hal ini bertujuan untuk meningkatkan kinerja karyawan dan mempermudah kegiatan operasional perusahaan. Dalam penambahan karyawan perlu juga diperhatikan latar belakang pendidikan berbasis pelayaran, agar proses pengurusan dan pelayanan kapal dapat berjalan dengan lancar. Namun perlu diperhatikan segi pengeluaran tunjangan atau gaji untuk karyawan.

b. Pemberian bonus serta reward Pemberian bonus dan reward kepada karyawan yang berprestasi dan karyawan yang mepunyai jenjang karir yang cukup lama agar lebih giat dan antusias dalam bekerja. Hal ini dapat dilakukan dengan:

1) pemberian tunjangan-tunjangan seperti: tunjangan kesehatan, tunjangan hari raya, tunjangan transportasi, dan tunjangan makan karyawan.

2) Pemberian adiah dan penghargaan kepada karyawan yang berprestasi dalam pekerjaan yang dapat menyelesaikan dengan cepat dan tepat. Serta kepada karyawan yang telah loyal lama bekerja dengan 
perusahaan, seperti memberikan kenaikan jabatan.

\section{Kurangnya keterampilan yang dimiliki karyawan divisi operasional dalam melakukan kegiatan keagenan kapal}

a. Pemberian pelatihan dan pendidikan kepada karyawan mengenai keagenan

Peningkatan keterampilan karyawan dalam kegiatan keagenan kapal yaitu dengan pemberian pelatihan dan pendidikan sehingga memiliki kemampuan dalam melaksanakan kegiatan pelayanan keagenan secara maksimal. Pelatihan dan pendidikan terhadap karyawan bermanfaat untuk meningkatkan keterampilan teknis, teoritis dan moral karyawan. Dengan demikian karyawan akan bertambah pengetahuannya dan akan meningkatkan kinerjanya.

Hal ini dapat dilakukan dengan:

1) Memberi khursus Bahasa Inggris kepada karyawan karena perusahaan juga mengageni kapal asing.

2) Memberi pendidikan tentang keagenan pada karyawan yang berlatar belakang pendidikan bukan pelayaran.

b. Meningkatkan sikap disiplin dalam bekerja

Dalam sikap pekerjaan diperlukan sikap dan perilaku taat mematuhi peraturan yang ada agar siklus kegiatan berjalan lancar tanpa ada hambatan. Semakin baik disiplin karyawan, semakin tinggi prestasi kerja yang dapat dicapainya. Tanpa disiplin yang baik, sulit bagi organisasi perusahaan mencapai hasil yang optimal. Oleh karena itu pihak manajemen harus mengadakan pelatihan yang bertujuan untuk meningkatkan kedisiplinan dan keahlian serta sikap dan mental karyawan. Untuk mengatasi karyawan perusahaan yang tidak disiplin juga dapat dilakukan dengan cara memberikan pengawasan langsung terhadap perilaku, moral, sikap, gairah, kerja, dan prestasi kerja. Selain itu, juga memberikan tindakan pembinaan dan penegakan disiplin sesuai dengan jenis pelanggaran yang ditetapkan oleh perusahaan.

\section{KESIMPULAN}

Dari hasil penjelasan sebelumnya, dapat disimpulkan sebagai berikut:

\section{Rendahnya kinerja karyawan divisi operasional}

Kegiatan pelayanan keagenan merupakan hal penting dalam kinerja operasional dan perkembangan perusahaan, mengingat hal tersebut menjadi tolak ukur yang diharapkan oleh pihak perusahaan dan pihak pengguna jasa yang menginginkan pelayanannya. Namun dalam kenyataanya pelayanan yang diberikan oleh PT Bahari Eka Nusantara Jakarta masih kurang karena rendahnya kinerja karyawan pada divisi operasional yang mengakibatkan tidak tercapai target perusahaan karena kurangnya kapal yang diageni.

2. Kurangnya keterampilan yang dimiliki karyawan divisi operasional dalam melakukan kegiatan keagenan kapal

Dalam pelaksanaan kegiatan keagenan biasanya diadakan sebuah perencanaan termasuk penyediaan sarana dokumen sehingga kegiatan tersebut dapat berjalan dengan lancar, aman dan efisien. Perencanaan ini dapat dilaksanakan sebelum kapal tiba, mulai dari aspek dokumen hingga aspek-aspek yang lainya. Hal ini dapat dilakukan dengan cara mempersiapkan, menetapkan, mengalokasikan, dan mengevaluasi dokumen-dokumen serta tenaga kerja yang diperlukan baik secara kuantitatif maupun secara kualitatif sehingga dapat memberikan hasil yang maksimal. Namun rendahnya keterampilan karyawan dalam melakukan kegiatan keagenan kapal mengakibatkan pelaksanaan operasional berjalan dengan lambat.

Adapun saran yang dapat peneliti berikan diantaranya:

\section{Rendahnya kinerja karyawan divisi operasional}

a. Menambah karyawan yang profesional Penambahan karyawan yang profesional sesuai standar perusahaan terutama karyawan pada divisi operasional 
merupakan salah satu pemecahan masalah yang dapat dilakukan oleh perusahaan untuk membantu meningkatkan kinerja karyawan lainnya dalam pengoperasian kapal. Penambahan jumlah karyawan dilakukan agar pekerjaan yang ada di perusahaan dapat diselesaikan secara efektif dan efisien.

b. Pemberian bonus serta reward

Pemberian bonus dan reward kepada karyawan yang berprestasi dan karyawan yang mepunyai jenjang karir yang cukup lama serta kepada karyawan yang telah loyal lama bekerja dengan perusahaan, seperti memberikan kenaikan jabatan agar lebih giat dan antusias dalam bekerja. Hal ini bisa menjadi motivasi kerja bagi para karyawan dalam melakukan.

2. Kurangnya keterampilan yang dimiliki karyawan divisi operasional dalam melakukan kegiatan keagenan kapal

a. Pemberian pelatihan dan pendidikan kepada karyawan mengenai keagenan

Peningkatan keterampilan karyawan dalam kegiatan keagenan kapal yaitu dengan pemberian pelatihan dan pendidikan sehingga memiliki kemampuan dalam melaksanakan kegiatan pelayanan keagenan secara maksimal. Pelatihan dan pendidikan terhadap karyawan bermanfaat untuk meningkatkan keterampilan teknis, teoritis dan moral karyawan. Dengan demikian karyawan akan bertambah pengetahuannya dan akan meningkatkan kinerjanya.

b. Meningkatkan sikap disiplin dalam bekerja

Pihak manajemen harus mengadakan pelatihan yang bertujuan untuk meningkatkan kedisiplinan dan keahlian serta sikap dan mental karyawan. Untuk mengatasi karyawan perusahaan yang tidak disiplin juga dapat dilakukan dengan cara memberikan pengawasan langsung terhadap perilaku, moral, sikap, gairah, kerja, dan prestasi kerja. Selain itu, juga memberikan tindakan pembinaan dan penegakan disiplin sesuai dengan jenis pelanggaran yang ditetapkan oleh perusahaan. Dalam meningkatkan pekerjaan diperlukan sikap dan perilaku taat mematuhi peraturan yang ada agar siklus kegiatan berjalan lancar tanpa ada hambatan. Semakin baik disiplin karyawan, semakin tinggi prestasi kerja yang dapat dicapainya. Tanpa disiplin yang baik, sulit bagi organisasi perusahaan mencapai hasil yang optimal.

\section{DAFTAR PUSTAKA}

[1] Abbas, Salim. 1993. Manajemen Transportasi. Jakarta: PT Raja Grafindo.

[2] Danim, Sudarawan. 2010. Administrasi Sekolah dan Manajemen Kelas. Bandung: Pustaka Setia

[3] Kosasih,Engkos dan Hananto. 2007. Manajemen Keuangan dan Akuntansi Perusahaan Pelayaran, Jakarta: Rajawali Pers

[4] Nurlaila. 2010. Manajemen Sumber Daya Manusia I. Ternate: Penerbit Lepkhair

[5] Hasibuan, Malayu S. P. 2001. Manajemen Sumber Daya Manusia. Jakarta: PT Bumi Aksara

[6] Rivai, Veithzal. 2009. Manajemen Sumber Daya Manusia untuk Perusahaan. Jakarta: Raja Grafindo Persada

[7] Siagian, Sondang. 2012. Manajemen Sumber Daya Manusia. Jakarta: PT Bumi Aksara

[8] Winardi. 1999. Pengantar tentang Teori Sistem dan Analisis Sistem. Jakarta: PT Karya Nusantara

[9] Yohannes, Yahya. 2006. Pengantar Manajemen. Yogyakarta: Graha Ilmu 